\title{
MIR218-1 wt Allele
}

National Cancer Institute

\section{Source}

National Cancer Institute. MIR218-1 wt Allele. NCI Thesaurus. Code C82169.

The human MIR218-1 wild-type allele is located in the vicinity of 4p15,31 and is approximately 109 bases in length. This allele, which encodes MIR218-1 pre-miRNA, plays a role in the regulation of gene expression. Alteration in the expression of this gene is associated with development of cervical cancer. 